\title{
STUDIES ON GROWTH RATE OF YELLOW NOTOTHENIA, NOTOTHENIA GIBBERIFRONS LÖNNBERG, 1905 OFF SOUTH GEORGIA
}

\author{
BADANIA NAD SZYBKOŚCIĄ WZROSTU ŻÓŁTEJ NOTOTENII, \\ NOTOTHENIA GIBBERIFRONS \\ LÖNNBERG, 1905, Z REJONU POŁUDNIOWEJ GEOORGII
}

\author{
Institute of Fisheries Oceanography \\ and Protection of Sea, \\ Academy of Agriculture, Szczecin
}

\begin{abstract}
The paper demostrates that scales are not suitable for back readings, due to a poor legibility of their central parts, the peripheral regions being poorly legible in older fish scales as well. One can presume that the scales begin to grow as late as in the second year of life. Most otoliths (sagitta) can be used in back calculations. Based on measurements of radii of various growth zones on the otolith cross-section, mean lengths attained in subsequent years of life were calculated. The von Bertalanffy growth equation parameters were estimated as follows: $L_{\infty}=57.48 \mathrm{~cm} ; \mathrm{K}=1.04$; $\mathrm{t}_{0}=0.439 \mathrm{yr}$. The mean length at first maturity was estimated at $37.5 \mathrm{~cm}$, i.e., $65 \%$ of $\mathrm{L}_{\infty}$.
\end{abstract}

\section{INTRODUCTION}

The yellow notothenia, Notothenia gibberifrans, is one of more important economically notothenids. The species played a major role in the reconnaissance catches of the RV "Profesor Siedlecki" in 1978/1979, its contribution to the total catch amounting to 25\% (Skóra, 1979). The species was also important in catches of German Antarctic 
expeditions (Kock, 1978, 1979, 1982). Biology of N.gibberifrons is still poorly known, though. Out of 4 papers dealing with the growth rate, that of Boronin and Frolkina (1978) is based on mean length in age groups, while Sust and Pinskaja (1978) worked with scale back reading on the assumption of a direct relationship between the total body length and scale radius length. Ciechanowski (1980) employed Wowk's procedure of age back reading from scales to study the yellow notothenia growth rate, while Boronin and Altman (1979) estimated the von Bertalanffy equation parameters and natural mortality coefficient from earlier data.

The objective of the present work was to examine the utility of scales and otoliths in growth rate back calculations.

\section{MATERIALS AND METHODS}

The materials for the work presented were collected in late March and in May 1977, during the 2nd Polish Antarctic Expedition, on fishing grounds NE off South Georgia, the trawl ground rope being provided with bobbins and chains as an auxiliary weights and its codend with a fine mesh ( $20 \mathrm{~mm}$ mesh size) insertion. The mean trawling depth ranged from 190 to $280 \mathrm{~m}$. The yellow notothenia occurred in each haul, contributing to 5-60\% of the catches. The species was most abundant at depths exceeding $250 \mathrm{~m}$. Additionally, the catches contained some other species, e.g., N. rossii marmorata Fischer, 1885; Pseudochaenichthys georgianus Norman, 1937; Chaenocephalus aceratus (Lönnberg, 1906); Champsocephalus gunnari Lönnberg, 1905; Trematomus hansoni Boulenger, 1902.

Thirteen samples of fish were collected*. The total body length was measured to $0.5 \mathrm{~cm}$ on 907 individuals; additionally, the caudal length (1.c.) was measured. Scales were collected directly behind the end of the pectoral fin from 490 individuals. Otoliths were collected from 488 individuals. The scales, soaked in $\mathrm{KOH}$ and thoroughly cleaned, were placed between two cover glasses and examined under a microfilm reader. Scale contours were drawn on a sheet of paper placed on the reader screen । $(17.5 \mathrm{x}$ magnification $)$ and the oral radius was measured to $1 \mathrm{~mm}$ from the drawing with a ruler (Fig. 1). A total of 213 individuals yielded scales for the oral radius measurements. The otcliths were burned in an ovenproof glass vessel until orange-colored, broken transversely in two parts, and the broken surfaces were, when necessary, polished with a fine grain sandpaper. The otolith parts were mounted, the broken surface up, and viewed under a stereomicroscope in incident light. Growth zones visible on the broken surface were measured to $0.01 \mathrm{~mm}$ under a microscope with the micrometric screw, a section from the centre to the dorsal margin being measured (Fig. 2). In older fish, the increments on the otolith section

* As the project was aimed at studying growth rate and feeding (described in a separate paper; Kompowski, in prep.), the fish of extremal body lengths - very large and very small ones - were preferred when sampling. 


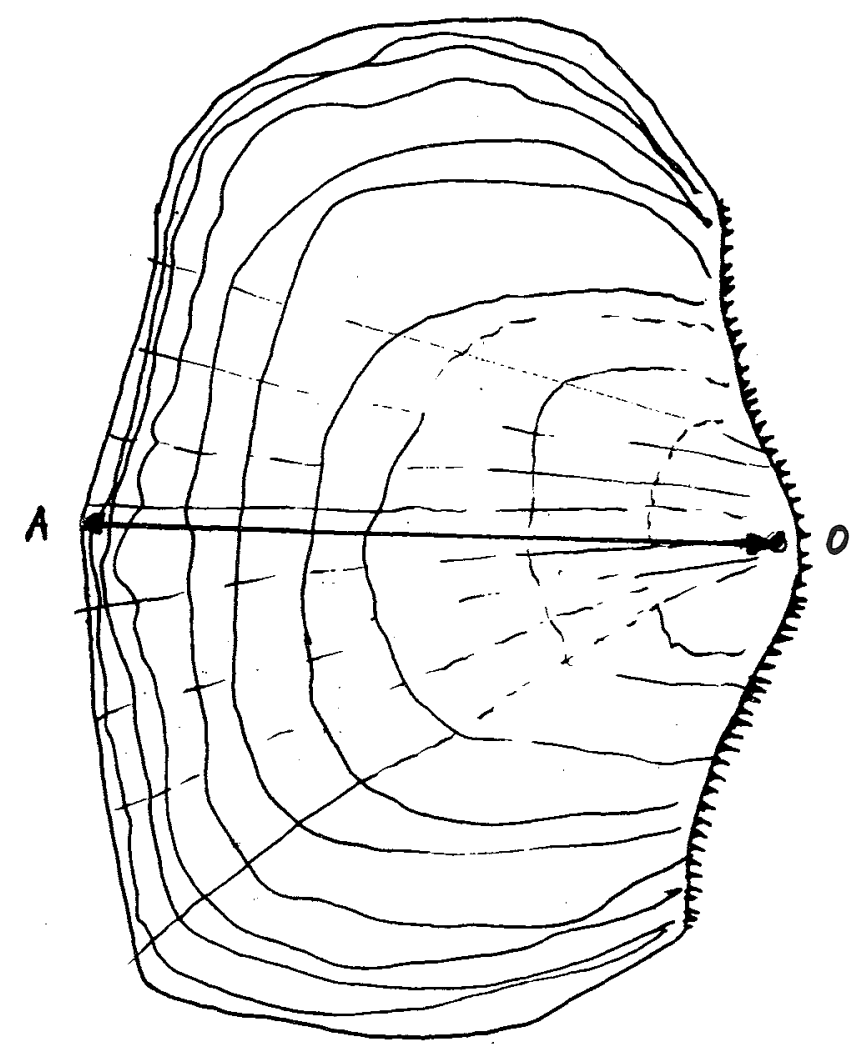

Fig. 1. Scale measurements in Notothenia gibberifrons

measured tended to deviate toward the internal margin (Fig. 5); this deviation, however, was usually small and therefore disregarded in calculations. A total of 266 fish individuals yielded otoliths for measurements. The procedures employed in back calculations are presented in a relevant section. The fish were sexed and the Maier scale gonad maturity stage determined in 487 individuals.

The measurements and determinations made are summarised in Table 1.

\section{FISH LENGTH AND AGE}

Total length - body length relationship

When recording the size of the Antarctic fish, the total body length (1.t.) is used most often. Some authors, however, use the body length (l.c.), i.e., the fish length is measured along the body to the outer margin of caudal scales. In order to compare growth data resulting from the two procedures, the total length - body length relationship was 


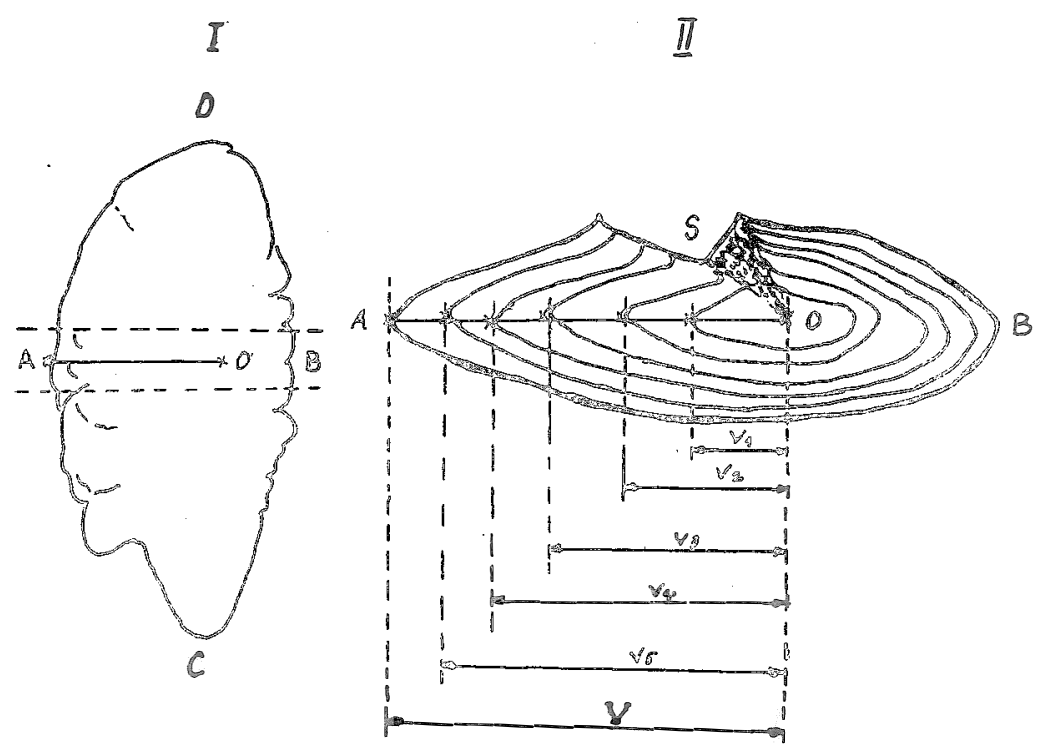

Fig. 2. Otolith measurements in Notothenia gibberifrons

I. External appearance of otolith; place of breakage marked with dashed line

A. dorsal margin, B. ventral margin, C. oral part, D. caudal part.

II. Otolith broken surface; $\mathrm{OA}=$ measured section; $\mathrm{O}=$ otolith nucleus; $\mathrm{S}=$ sulcus acusticus

looked into. In the yellow notothenia $13.5-50 \mathrm{~cm}$ long (1.t.) the relationship is almost linear and can be described by an equation of $y=a+b x$ type (Fig. 3). The equation parameters $\mathrm{a}$ and $\mathrm{b}$ were estimated by the least squares method, which yielded

$$
\text { 1.c. }=0.8848 \text { 1.t. }-0.3801
$$

$$
\mathrm{r}=0.9994
$$

where

$$
\begin{aligned}
& \text { 1.c. }=\text { body length }(\mathrm{cm}) \\
& \text { 1.t. }=\text { total length }(\mathrm{cm})
\end{aligned}
$$

\section{LENGTH OF FISH CAUGHT}

The fish caught ranged fairly widely in length, from 13.5 to $50.0 \mathrm{~cm}$. The juveniles usually accompanied the adults. Those individuals measuring from 35 to $45 \mathrm{~cm}$ contributed the highest biomass to the catches (Fig. 4). 
Table 1

Materials collected and analyses performed (no. of individuals examined)

\begin{tabular}{|c|c|c|c|c|c|c|c|c|c|}
\hline \multirow[b]{2}{*}{ Np. } & \multirow[b]{2}{*}{ Fishing site coordinates } & \multirow[b]{2}{*}{ Date } & \multirow{2}{*}{$\begin{array}{l}\text { Mean } \\
\text { trawling } \\
\text { depth } \\
\text { (m) }\end{array}$} & \multicolumn{6}{|c|}{ Measurements } \\
\hline & & & & Length & $\begin{array}{l}\text { No. of oto- } \\
\text { lith pairs } \\
\text { collected }\end{array}$ & $\begin{array}{l}\text { Otolith } \\
\text { measured }\end{array}$ & $\begin{array}{c}\text { Scales } \\
\text { measured }\end{array}$ & $\begin{array}{c}\text { Sex and } \\
\text { gonad } \\
\text { determined }\end{array}$ & $\begin{array}{l}\text { No. of } \\
\text { legible } \\
\text { otoliths }\end{array}$ \\
\hline 1. & $54^{\circ} 06^{\prime} \mathrm{S} ; 36^{\circ} 07^{\prime} \mathrm{W}$ & $22 . I I I / 2$ & 280 & 23 & 23 & 12 & 16 & 23 & 23 \\
\hline 2. & $53^{\circ} 58^{\prime} \mathrm{S} ; 36^{\circ} 03^{\prime} \mathrm{W}$ & $23 . \mathrm{III} / 2$ & 280 & 23 & 22 & 12 & 17 & 23 & 22 \\
\hline 3. & $54^{\circ} 33^{\prime} \mathrm{S} ; 35^{\circ} 31^{\prime} \mathrm{W}$ & $6 . \mathrm{V} / 3$ & 290 & 53 & 53 & 30 & 38 & 52 & 52 \\
\hline 4. & $54^{\circ} 25^{\prime} \mathrm{S} ; 35^{\circ} 34^{\prime} \mathrm{W}$ & $9 . \mathrm{V} / 2$ & 280 & 54 & 54 & 38 & 47 & 54 & 51 \\
\hline 5. & $54^{\circ} 04^{\prime} \mathrm{S} ; 36^{\circ} 01^{\prime} \mathrm{W}$ & $10 . \mathrm{V} / 2$ & 280 & 28 & 28 & 19 & 25 & 28 & 23 \\
\hline 6. & $54^{\circ} 04^{\prime} \mathrm{S} ; 36^{\circ} 09^{\prime} \mathrm{W}$ & 11.V/1 & 280 & 50 & 50 & 21 & 20 & 49 & 49 \\
\hline 7. & $54^{\circ} 04^{\prime} \mathrm{S} ; 36^{\circ} 17^{\prime} \mathrm{W}$ & 14. $V / 2$ & 280 & 299 & - & - & - & - & - \\
\hline 8. & $54^{\circ} 07^{\prime} \mathrm{S} ; 35^{\circ} 47^{\prime} \mathrm{W}$ & $17 . V / 3$ & 240 & 57 & 57 & 28 & 9 & 57 & 55 \\
\hline 9. & $54^{\circ} 03^{\prime} \mathrm{S} ; 35^{\circ} 49^{\prime} \mathrm{W}$ & $18 . \mathrm{V} / 4$ & 240 & 63 & 62 & 30 & 3 & 63 & 55 \\
\hline 10. & $53^{\circ} 55^{\prime} \mathrm{S} ; 36^{\circ} 17^{\prime} \mathrm{W}$ & 19.V/4 & 220 & 26 & 25 & 23 & - & 26 & 25 \\
\hline 11. & $54^{\circ} 04^{\prime} \mathrm{S} ; 36^{\circ} 19^{\prime} \mathrm{W}$ & $23 . \mathrm{V} / 2$ & 280 & 29 & 29 & 11 & - & 29 & 29 \\
\hline 12. & $54^{\circ} 29^{\prime} \mathrm{S} ; 35^{\circ} 31^{\prime} \mathrm{W}$ & $24 . V / 3$ & 270 & 42 & 42 & 24 & 25 & 42 & 39 \\
\hline 13. & $54^{\circ} 29^{\prime} \mathrm{S} ; 35^{\circ} 30^{\prime} \mathrm{W}$ & $26 . \mathrm{V} / 2$ & 275 & 160 & 43 & 18 & 13 & 43 & 39 \\
\hline & & & Total & 907 & 488 & 266 & 213 & 489 & 462 \\
\hline
\end{tabular}




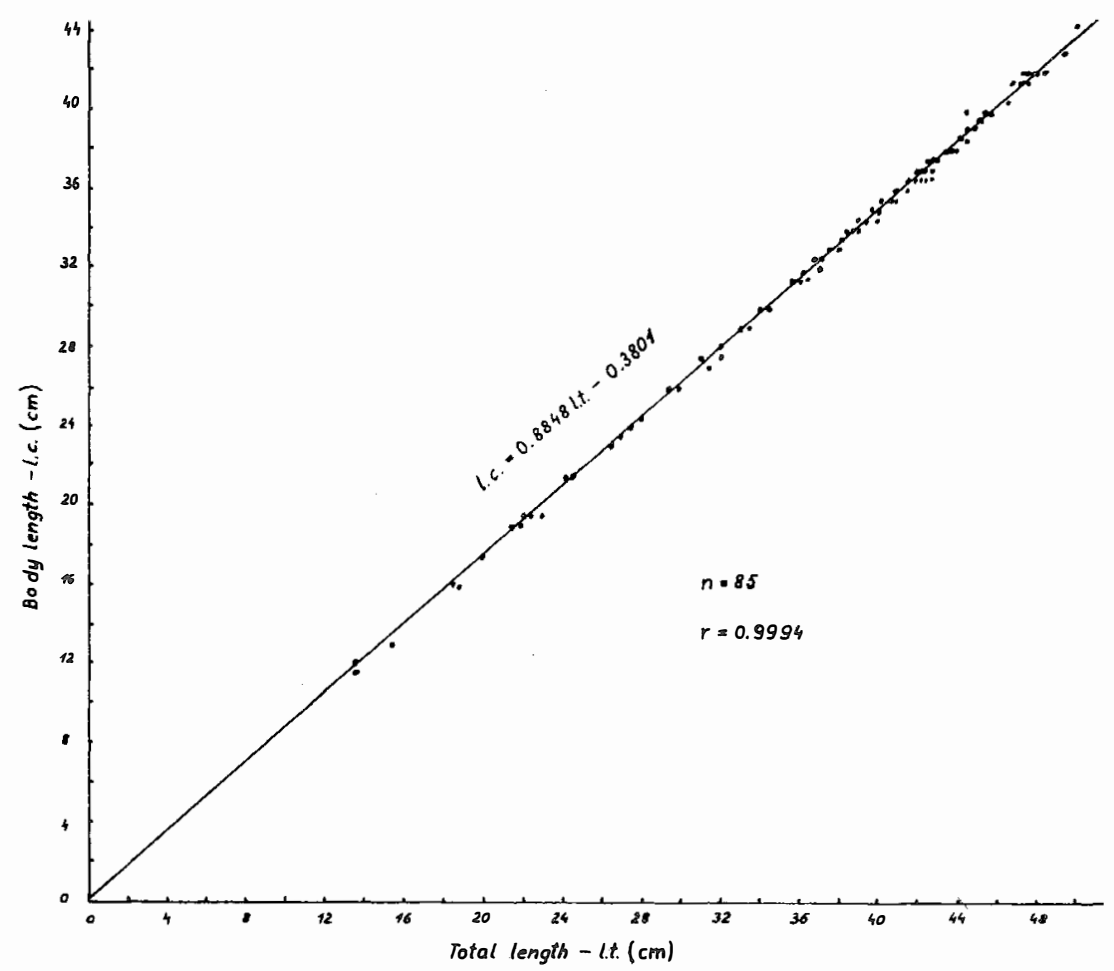

Fig. 3. Total length - body length relationship in Notothenia gibberifrons off South Georia

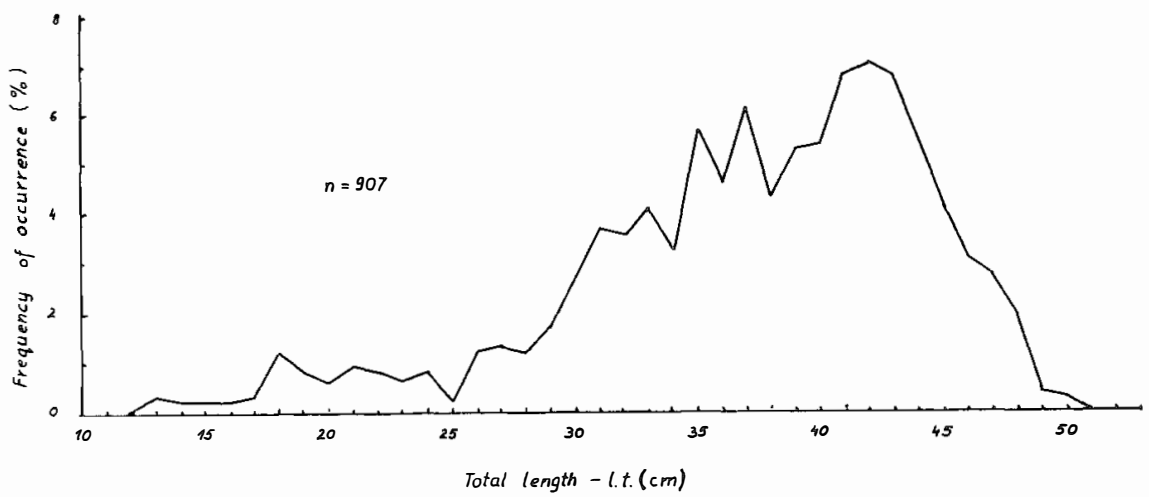

Fig. 4. Notothenia gibberifrons length distribution in bottom trawl catches off South Georgia in March and May 1977 

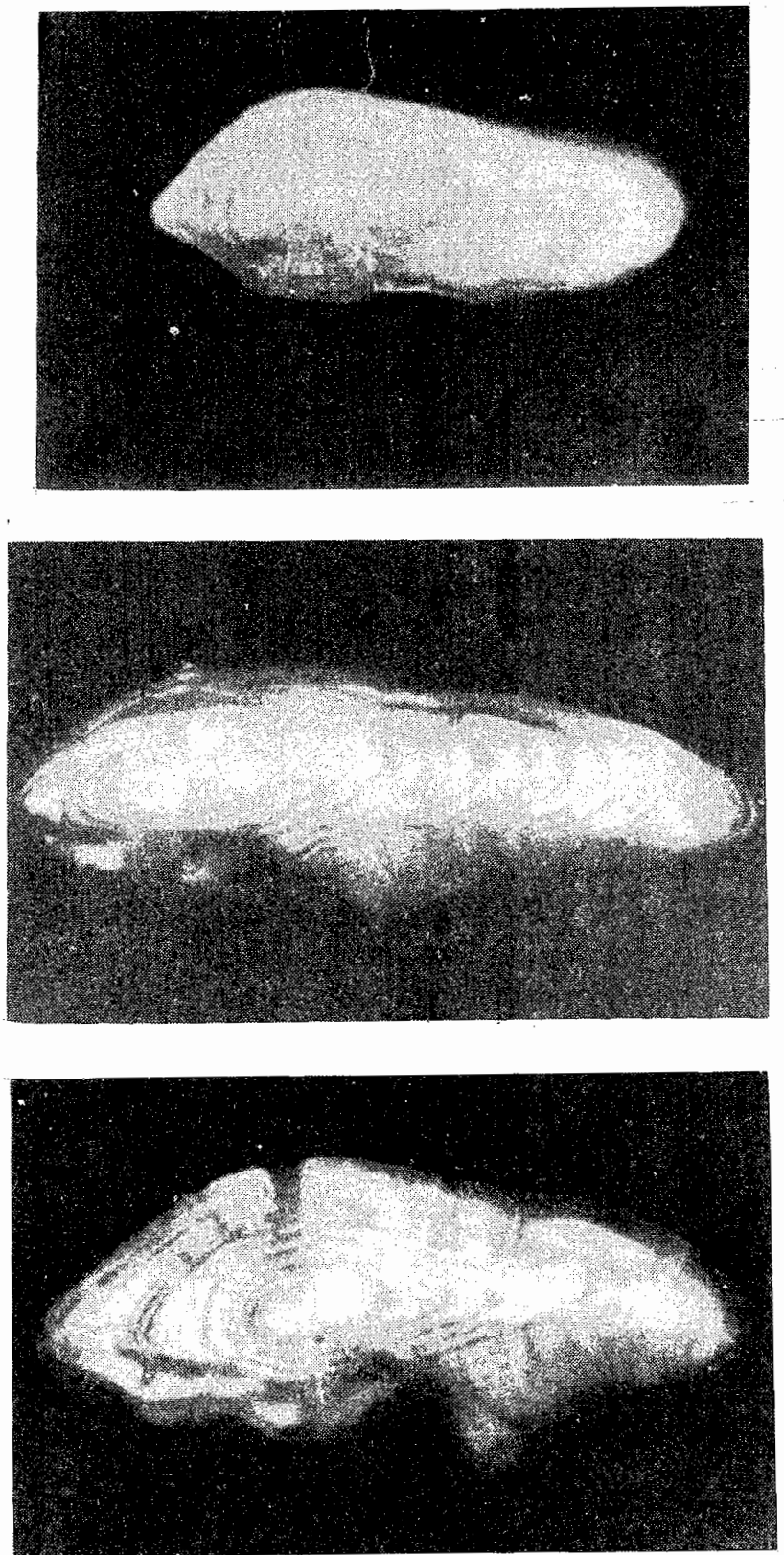

Fig. 5. Notothenia gibberifrons otoliths:

A. Date of capture May 17, 1977; 1.t. $16.5 \mathrm{~cm}$; age 3+; magnification $23.8 \mathrm{x}$

B. Date of capture May 6, 1977; 1.t. $45.0 \mathrm{~cm}$; ठ V; age $16+$; magnification $16.1 \mathrm{x}$

C. Date of capture May 6, 1977; 1.t. $46.0 \mathrm{~cm}$; $\delta$ V; age approx. 20; magnification $16.4 \mathrm{x}$ 


\section{AGE OF FISH CAUGHT}

Broken surfaces of the otoliths, often without any prior polishing, showed concentric layers (zones) made of alternating opaque and hyaline substances (Fig. 5). The otolith margin was opaque. The fish age was determined by counting annual increments, assuming that an annual increment consists of an opaque zone and an adjacent hyaline one, as is the case in other fish species. Otoliths of 488 individuals were examined, 462 yielding legible otoliths.

The material studied comprised fishes aged from $2+$ to $23+\mathrm{yr}$ (Fig. 6). The determined age of fishes older than $15 \mathrm{yr}$ is frequently an approximation only and in reality can be 1 or $2 \mathrm{yr}$ higher or lower. Most illegible and therefore discarded otoliths were collected from older fishes, aged presumably more than $15 \mathrm{yr}$. For this reason, and also because of the bias towards younger individuals in detailed analyses, a real contribution of old fishes was likely to be slightly higher than that presented in Fig. 6.

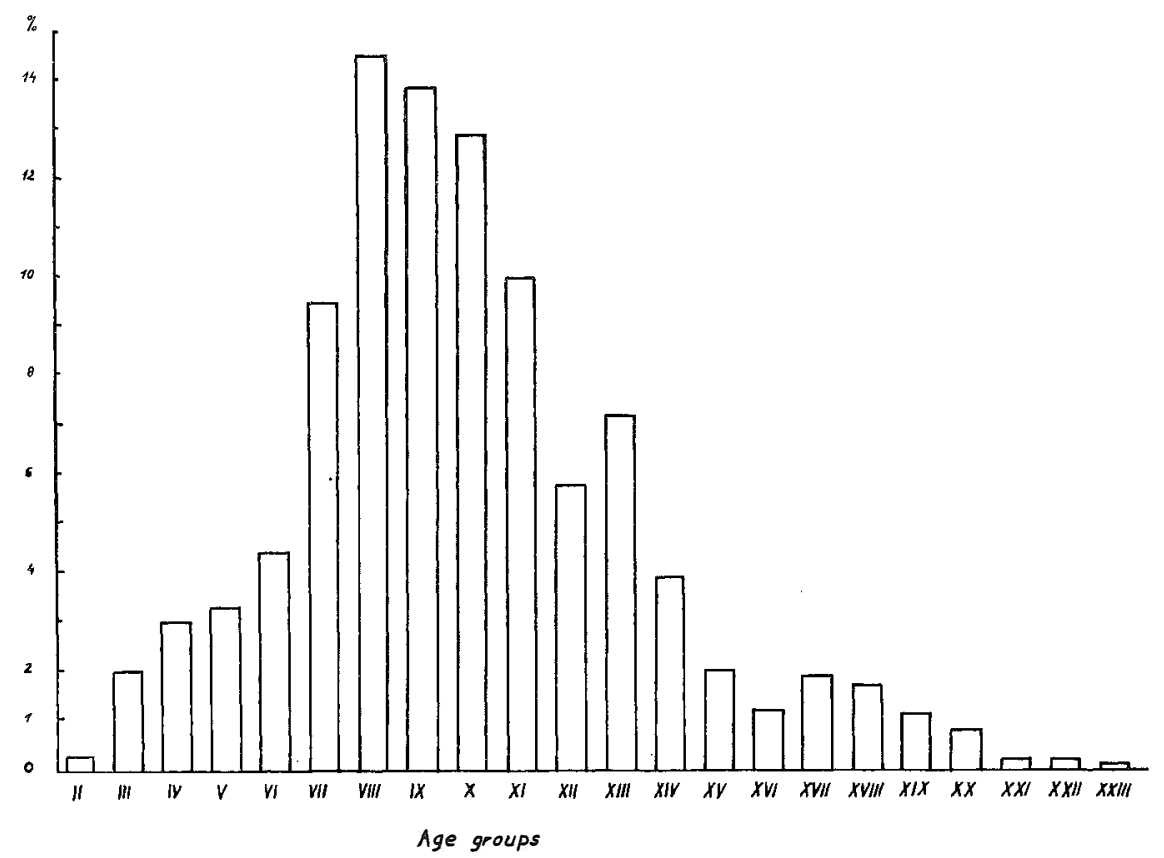

Fig. 6. Notothenia gibberifrons age distribution in bottom trawl catches off South Georgia in March and May 1977

\section{GROWTH RATE}

Scale oral radius - total length relationship

The yellow notothenia scales are relatively large; as their collection and storage present no greater difficulties, an attempt was made to utilise them in growth rate back 
calculations. However, it was difficult to interpret annual rings (zones of closely packed sclerites). The first 3 or 4 'ings are very poorly separated (Fig. 7B). Farther rings are fairly clearly set off, but often divided or accompanied by false ones difficult to distinguish from the proper rings. In older fish it was very difficult or even impossible to separate the rings located close to the scale margin.
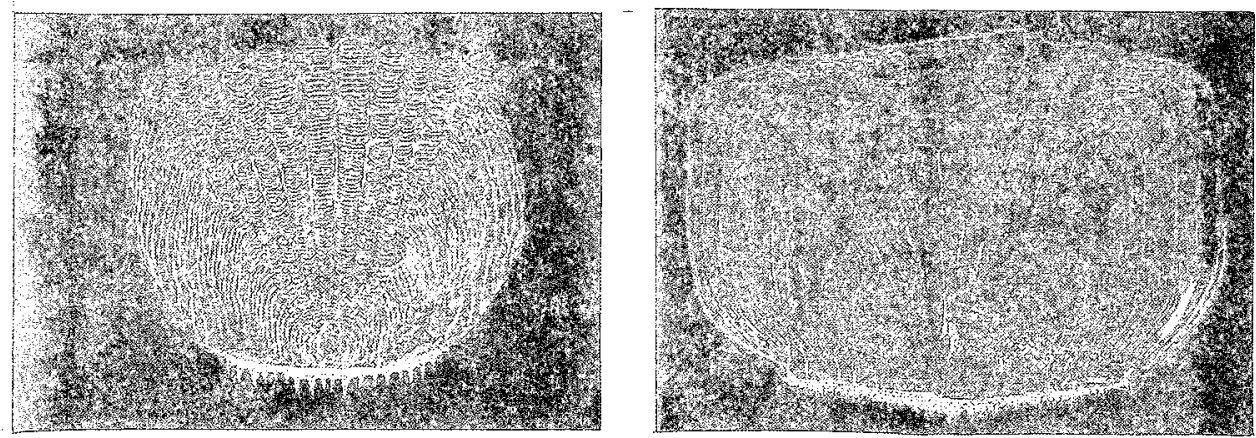

Fig. 7. Notothenia gibberifrons scales:

A. Date of capture May 26, 1977; 1.t. $18.5 \mathrm{~cm}$; age $3+$; magnification $27 \mathrm{x}$

B. Date of capture May 6, 1977; 1.t. $45.0 \mathrm{~cm}$; $0 \hat{\mathrm{V}} \mathrm{V}$; age $16+$; magnification $12.6 \mathrm{x}$

Fig. 8 presents the results of scale oral radius measurements, the scales being collected from individuals ranging in size within $13.5-50.0 \mathrm{~cm}$. The scale oral radius - total length relationship is curvilinear, the curvilinearity resulting grom a gradual change in the shape of a scale with fish growth (Fig. 7). The following parabolic equation was fitted (the least squares method) to the empirical data:

$$
\mathrm{V}=-22.3487+3.9466 \text { 1.t. }-0.02477(1 . \mathrm{t} .)^{2}
$$

where

$$
\begin{aligned}
\mathrm{V} & =\text { scale oral radius } \mathrm{x} 17.5(\mathrm{~mm}), \\
\text { l.t. } & =\text { total length }(\mathrm{cm}) .
\end{aligned}
$$

The curve described by the above equation, when extrapolated beyond the empirical data, intersects the abscissa at $1 . t$. of $5.8 \mathrm{~cm}$. If, then, the relationship holds also for the fishes smaller than the smallest one found by the author $(13.5 \mathrm{~cm} \mathrm{1.t.)}, N$. gibberifrons is likely to start the scales at the total length of $5.8 \mathrm{~cm}$, on the average. A possibility cannot be excluded that, at least in some fishes, the scales do not appear until the age of 1 and more. If so, such scales would lack the first annual ring. To investigate the matter further, studies on $N$.gibberifrons fry are required.

In view of the difficulties in the interpretation of annual rings, and owing to the presumably delayed growth of scales, they were not considered in back calculations in spite of numerous measurements of growth zones made. 


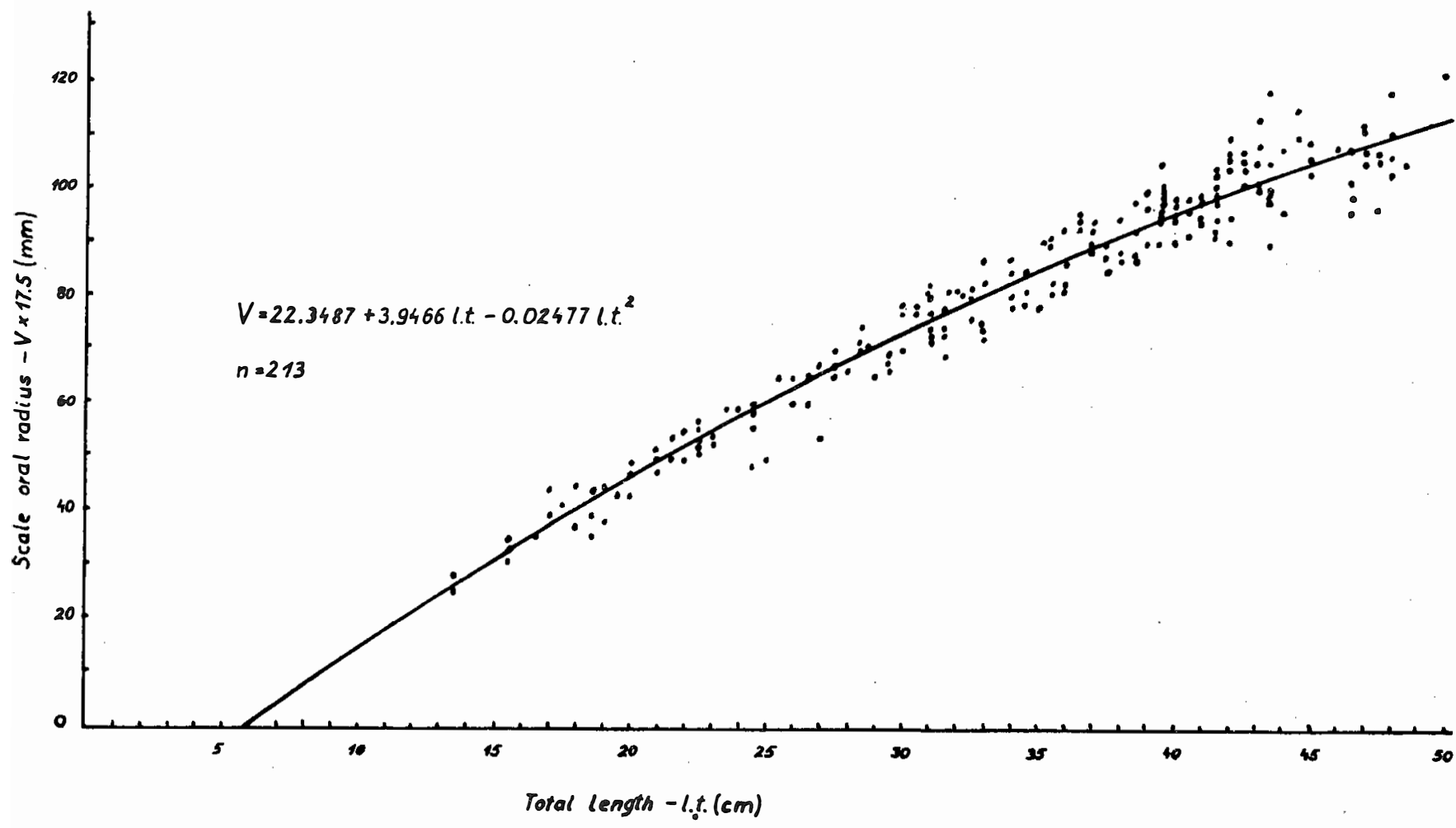

Fig. 8. Relationship between scale oral radius (V) and total length in Notothenia gibberifrons off South Georgia 


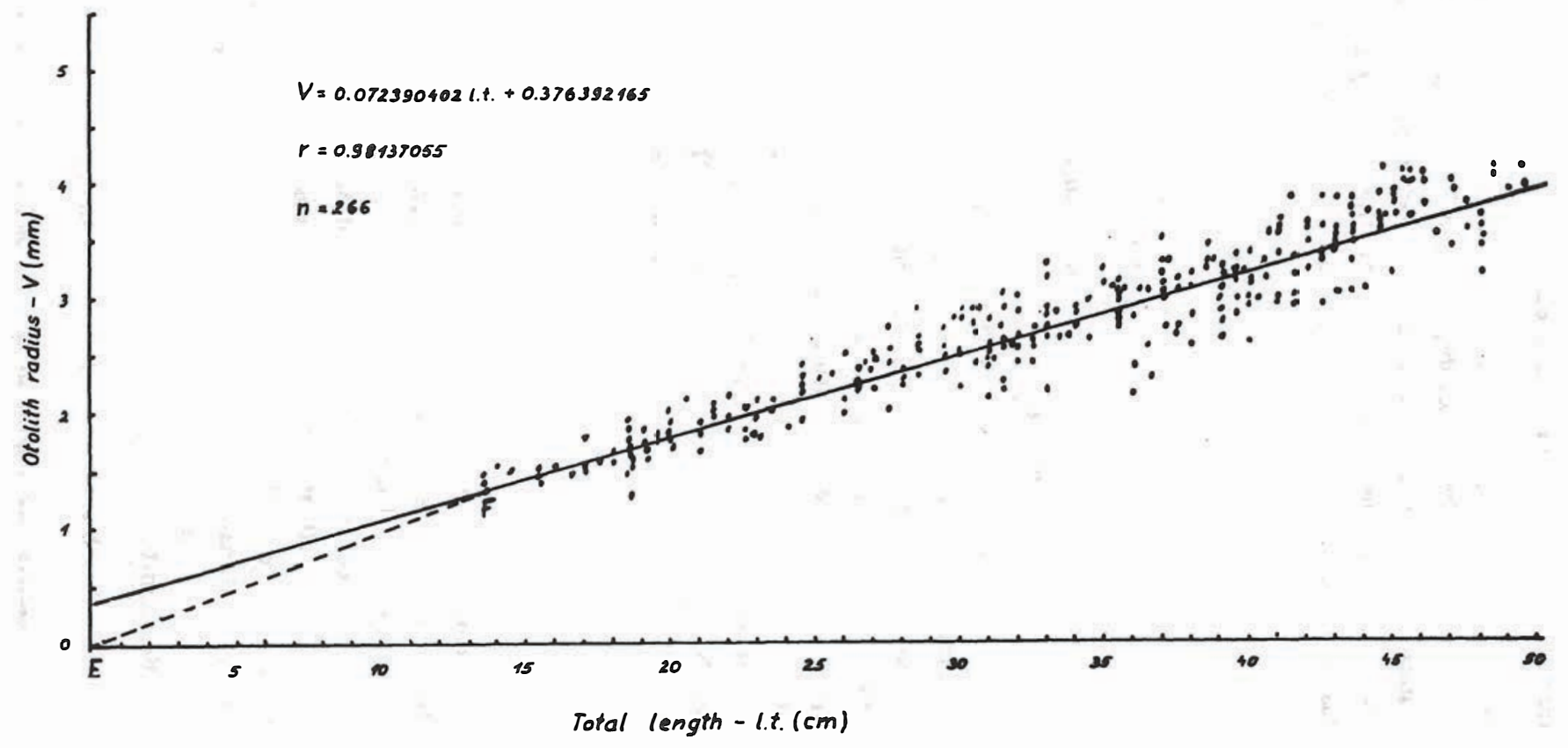

Fig. 9. Relationship between otolith cross-section radius (V) as measured between nucleus and dorsal margin and total length in Notothenia gibberifrons off South Georgia. Dashed line (EF) denotes arbitrarily adopted simplified course of relationship from coordinates origin to lower limit of empirical data 
Otolith cross-section dorsal radius - total length relationship

Fig. 9 presents data on the cross-section dorsal radius of the otoliths collected from fishes $13.5-49.5 \mathrm{~cm}$ long (1.t.). The relationship between the radius and the total length is close to linear within the fish length range studied. A linear equation describing the relationship was fitted to the empirical data by the least squares method. The calculations are based on the mean radii for $0.5 \mathrm{~cm}$ fish length classes. The equation is as folows:

$$
\mathrm{V}=0.07239 \text { 1.t. }+0.3764
$$

or

$$
\text { 1.t. }=13.814 \mathrm{~V}-5.1995
$$

where $\quad \mathrm{V}=$ otolith cross-section dorsal radius $(\mathrm{mm})$

$$
\text { 1.t. }=\text { total length }(\mathrm{cm})
$$

A high, close to unity, correlation coefficient $(r=0.9814)$ points to a good fit of the equation to the empirical data. However, the line described by the equation intersects the ordinate at some distance from the origin (Fig. 9). One can thus conclude that the fish smaller than the lower limit of the range studied, i.e., $13.5 \mathrm{~cm}$, the otolith radius-total length relationship is of a different nature., At present, however, the lack of data prevents any explanation of the problem. Assuming some simplification, a straight line was drawn between the data point on the line corresponding to the lower size limit and the origin, although the relationship here may be curvilinear. This simplified relationship was adopted in the other of the two methods of back calculations.

\section{BACK CALCULATIONS}

The N.gibberifrons growth rate was calculated by means of two methods.

The first one involves calculating the mean radius of each growth zone, which results in otolith growth rate (Table 2). Then the lengths attained by the fish in consecutive years of life were reconstructed by inserting mean radii of otolith growth zones into the equation (3) describing the growth zone radius-fish total length relationship. The results obtained are presented in Table 3. The results for lengths in the first and second years of life are most likely underestimates as the equation(3) is fitted to the empirical data within the range of $13.5-49.5 \mathrm{~cm}$ total length. Based on data from Table 3 , the following parameters of the von Bertalanffy equation were estimated:

$$
\mathrm{L}_{\infty}=57.48 \mathrm{~cm} ; \mathrm{K}=0.1040 ; \mathrm{t}_{0}=0.4391 \mathrm{yr} \text {. }
$$

When estimating the parameters, the lengths in age groups I, II, and III were disregarded. The asymptotic length $\left(\mathrm{L}_{\infty}\right)$ obtained is only slightly higher than the maximum length of N.gibberifrons recorded off South Georgia $(52 \mathrm{~cm}$, Sust and Pinskaja, 1978; $53 \mathrm{~cm}$, 
Otolith growth rate in Notothenia gibberifrons (mean otolith cross-section radius, $\mathrm{V}_{\mathrm{n}}$, in subsequent years of life)

\begin{tabular}{|c|c|c|c|c|c|c|c|c|c|c|c|c|c|c|c|}
\hline & $\mathrm{v}_{1}$ & $\mathrm{v}_{2}$ & $\mathrm{v}_{3}$ & $\mathrm{v}_{4}$ & $\mathrm{v}_{5}$ & $\mathrm{v}_{6}$ & $\mathrm{v}_{7}$ & $\mathrm{v}_{8}$ & $\mathrm{v}_{9}$ & $\mathrm{v}_{10}$ & $\mathrm{v}_{11}$ & $\mathrm{v}_{12}$ & $\mathrm{v}_{13}$ & $\mathrm{v}_{14}$ & $\mathrm{v}_{15}$ \\
\hline $\begin{array}{c}\mathrm{V}_{\mathrm{n}} \\
(\mathrm{mm})\end{array}$ & 0.62 & 1.02 & 1.36 & 1.67 & 1.94 & 2.20 & 2.43 & 2.64 & 2.81 & 3.01 & 3.17 & 3.28 & 3.45 & 3.49 & 3.62 \\
\hline$\pm \delta$ & 0.1178 & 0.1546 & 0.1948 & 0.2242 & 0.2439 & 0.2595 & 0.2620 & 0.2743 & 0.2625 & 0.2715 & 0.2851 & 0.2924 & 0.2308 & 0.1975 & 0.1570 \\
\hline$\pm_{\mathrm{m}}$ & 0.0078 & 0.0104 & 0.0131 & 0.0158 & 0.0182 & 0.0207 & 0.0221 & 0.0260 & 0.0290 & 0.0357 & 0.0416 & 0.0525 & 0.0481 & 0.0595 & 0.0555 \\
\hline $\mathrm{n}$ & 224 & 223 & 220 & 202 & 179 & 157 & 140 & 111 & 82 & 58 & 47 & 31 & 23 & 11 & 8 \\
\hline
\end{tabular}


Length growth rate of Notothenia gibberifrons (total length, 1.t., $\mathrm{cm}$ ) calculated from equation: L.t. $=13.814 \mathrm{~V}-5.1995$ by inserting mean otolith radius $\left(\mathrm{V}_{\mathrm{n}}\right)$ in each year; and theoretical growth rate according to von Bertalanffy equation

\begin{tabular}{|l|l|l|l|l|l|l|l|l|l|l|l|l|l|l|l|l|}
\hline \multirow{2}{*}{} & \multicolumn{8}{|c|}{ Mean fish length in subsequent years of life } \\
\cline { 2 - 11 } & & $\mathrm{L}_{1}$ & $\mathrm{~L}_{2}$ & $\mathrm{~L}_{3}$ & $\mathrm{~L}_{4}$ & $\mathrm{~L}_{5}$ & $\mathrm{~L}_{6}$ & $\mathrm{~L}_{7}$ & $\mathrm{~L}_{8}$ & $\mathrm{~L}_{9}$ & $\mathrm{~L}_{10}$ & $\mathrm{~L}_{11}$ & $\mathrm{~L}_{12}$ & $\mathrm{~L}_{13}$ & $\mathrm{~L}_{14}$ & $\mathrm{~L}_{15}$ \\
\hline Back calculations & & & & & & & & & & & & & & & \\
\hline
\end{tabular}


Skóra, 1979). Theoretical lengths in subsequent age groups as calculated by means of the equation are presented in Table 3. As can be seen, the theoretical lengths are close to data from back calculations. Boronin and Altman's (1979) estimation of growth parameters for the years 1969-1974 differs somewhat from the present results: $\mathrm{L}_{\infty}=52.9 \mathrm{~cm}$; $\mathrm{K}=0.15 ; \mathrm{t}_{0}=0.7 \mathrm{yr}$. The differences are most likely brought about by a different growth rate estimation method used by those authors.

The other method of back calculations is applied after Wowk (1955) with a modification such that the otolith radius corresponding to the length of a given fish was first read from the graph (Fig. 9). This radius was then divided by the real otolith radius of the fish measured. The quotient obtained was treated as a correction factor to multiply it by the otolith radius at a given age, and a fish length corresponding to the corrected radius was read from the graph. For length readings smaller than $13.5 \mathrm{~cm}$, an arbitrary, simplified otolith radius-fish length relationship was used, the relationship being expressed in Fig. 9 as a straight line connecting the coordinates origin with the lower limit of empirical data. The method described above allows to follow the individual variability in growth (Table 4), while the first procedure yields a mean growth rate only. As can be seen, individual variability in the $N$.gibberifrons growth rate is quite remarkable, particularly in the first few years of life.

The $N$.gibberifrons growth rates were followed separately in males and females to find out if there is any sexual dimorphism reflected in the species growth. Furthermore, growth rate of immature individuals (i.e., those in which sex could not be determined by eye) was examined as well. As seen from Table 4, growth rates of all three categories are similar. Boronin and Frolkina (1976) and Sust and Pinskaja (1978) did not observed any significant differences in growth rate between males and females either.

When the results obtained with the two methods are compared, a correspondence within the range of $\mathrm{L}_{3}-\mathrm{L}_{12}$ is observed. The differences in the results for age groups XIII-XIV are most likely brought about by a small amount of data collected. On the other hand, considerable discrepancies between the results for $\mathrm{L}_{1}$ and $\mathrm{L}_{2}$ obtained with the two methods are caused by the arbitrarily adopted curve reflecting the fish length-otolith radius relationship.

\section{LENGTH AND AGE AT FIRST MATURITY}

The catches contained both mature and immature individuals. Gonads of the mature ones were at the Maier scale stages II-VI, no higher stage being ever observed. The wide length range of the fish examined allowed to determine the length and age at the first maturity. Those individuals whose sex could not be distinguished by eye were considered immature (Maier scale stage I); the remaining ones were regarded as mature. A similar criterion of maturity was applied by Kock (1981) to 3 species of the family Chaenichthyidae. The results are presented in Fig. 10; as can be seen, up to $27.5 \mathrm{~cm}$ total 
Growth rate of Notohenia gibberifrons Lönnberg off South Georgia. Back calculations from otoliths;

Table 4 Wowk's procedure. Total length $(\mathrm{cm})$

\begin{tabular}{|c|c|c|c|c|c|c|c|c|c|c|c|c|c|c|c|c|}
\hline \multirow{2}{*}{$\mathrm{L}_{\mathrm{n}}$} & \multicolumn{4}{|c|}{ Immature individuals } & \multicolumn{4}{|c|}{ Males } & \multicolumn{4}{|c|}{ Females } & \multicolumn{4}{|c|}{ Total } \\
\hline & $\bar{x}$ & $\pm \delta$ & $\mathbf{n}$ & Range & $\overline{\mathrm{x}}$ & $\pm \delta$ & $\mathbf{n}$ & Range & $\bar{x}$ & $\pm \delta$ & $\mathrm{n}$ & Range & $\overline{\mathrm{x}}$ & $\pm \delta$ & $\mathrm{n}$ & Range \\
\hline $\mathrm{L}_{1}$ & 6.1 & 1.0712 & 135 & $3.3-8.8$ & 6.0 & 1.1344 & 37 & $3.4-9.3$ & 5.7 & 1.2386 & 32 & $3.4-8.8$ & 6.0 & 1.1202 & 204 & $3.3-9.3$ \\
\hline $\mathrm{L}_{2}$ & 10.0 & 1.4120 & 135 & $5.9-13.9$ & 10.3 & 1.8100 & 37 & $7.6-15.7$ & 10.0 & 1.5538 & 32 & $6.9-14.5$ & 10.1 & 1.5167 & 204 & $5.9-15.7$ \\
\hline $\mathrm{L}_{3}$ & 13.9 & 2.3022 & 132 & $8.8-21.5$ & 13.9 & 2.8469 & 37 & $9.7-21.5$ & 13.4 & 2.5043 & 32 & $9.5-20.9$ & 13.8 & 2.4514 & 201 & $8.8-21.5$ \\
\hline $\mathrm{L}_{4}$ & 18.2 & 2.8350 & 114 & $11.4-26.4$ & 18.1 & 3.3936 & 37 & $11.9-26.8$ & 17.3 & 2.6932 & 32 & $12.4-24.7$ & 18.0 & 2.9514 & 183 & $11.4-26.8$ \\
\hline $\mathrm{L}_{5}$ & 22.4 & 2.8469 & 94 & $15.4-29.3$ & 21.9 & 1.5007 & 37 & $15.3-31.5$ & 20.9 & 2.8556 & 32 & $15.4-27.8$ & 22.0 & 2.6663 & 163 & $15.3-31.5$ \\
\hline $\mathrm{L}_{6}$ & 26.0 & 2.6206 & 72 & $18.8-31.1$ & 25.2 & 3.8398 & 37 & $17.5-34.9$ & 24.3 & 2.9544 & 32 & $18.6-31.1$ & 25.4 & 3.1342 & .141 & $17.5-34.9$ \\
\hline $\mathrm{L}_{7}$ & 29.0 & 2.2839 & 61 & $22.2-34.0$ & 28.7 & 3.7195 & 37 & $22.0-36.9$ & 28.0 & 3.3881 & 31 & $21.6-37.4$ & 28.7 & 3.0593 & 129 & $21.6-37.4$ \\
\hline $\mathrm{L}_{8}$ & 31.5 & 2.4530 & 38 & $25.1-36.7$ & 31.4 & 3.3633 & 35 & $25.5-36.3$ & 31.4 & 3.4052 & 29 & $24.5-34.7$ & 31.5 & 3.0696 & 102 & $24.5-36.7$ \\
\hline $\mathrm{L}_{9}$ & 33.4 & 2.6200 & 20 & $27.5-38.5$ & 33.5 & 3.1776 & 30 & $28.0-38.0$ & 33.5 & 4.0322 & 25 & $28.7-38.1$ & 33.5 & 3.3600 & 75 & $27.5-38.5$ \\
\hline $\mathrm{L}_{10}$ & 34.4 & - & 4 & $33.1-35.9$ & 35.6 & 4.3166 & 26 & $30.1-40.2$ & 36.4 & 2.8935 & 23 & $29.5-40.0$ & 35.9 & 3.6294 & 53 & $29.5-40.2$ \\
\hline $\mathrm{L}_{11}$ & 36.9 & - & 1 & - & 37.5 & 6.1338 & 23 & $32.1-41.3$ & 38.8 & 3.0389 & 20 & $32.2-43.0$ & 38.1 & 2.8010 & 44 & $32.1-43.0$ \\
\hline $\mathrm{L}_{12}$ & -- & - & - & - & 39.5 & 2.2789 & 16 & $34.1-43.1$ & 39.7 & 2.5524 & 13 & $36.0-44.5$ & 39.5 & 2.4170 & 29 & $34.1-44.5$ \\
\hline $\mathrm{L}_{13}$ & - & - & - & - & 40.5 & 2.1670 & 12 & $35.5-43.7$ & 40.8 & - & 9 & $38.1-44.0$ & 40.6 & 2.0546 & 21 & $35.5-44.0$ \\
\hline $\mathrm{L}_{14}$ & - & - & - & - & 40.9 & - & 7 & $37.7-43.8$ & 42.0 & - & 3 & $40.7-43.7$ & 41.2 & - & 10 & $37.7-43.8$ \\
\hline
\end{tabular}




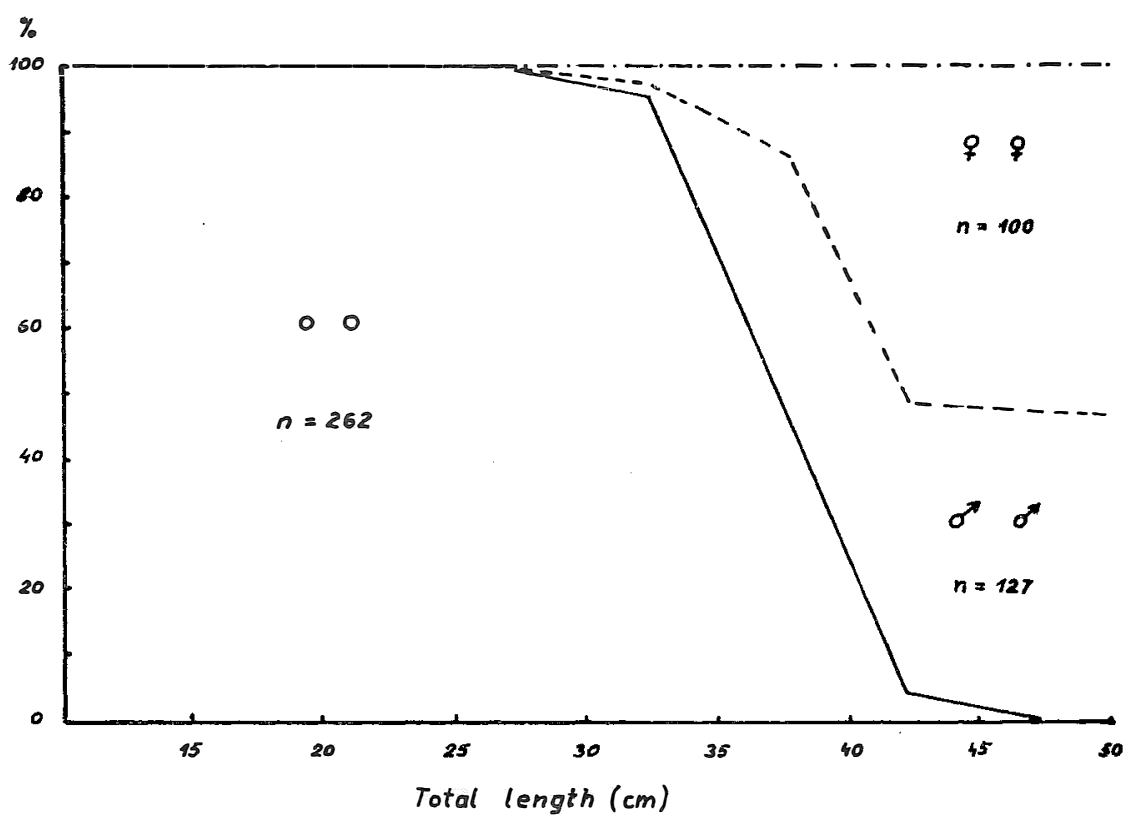

Fig. 10. Immature individuals (oo), females ( $\$ \%)$, and males ( $\left.0^{\circ}\right)^{\circ}$ in various length classes of Notothenia gibberifrons caught off South Georgia in March and May 1977. $n=489$.

length, i.e., up to approximately age 7,100\% of the fishes were immature. At $37.5 \mathrm{~cm}$ corresponding to the age of 10 , sex could not be determined by eye in about half (48.93\%) of the individuals examined. At $42.5 \mathrm{~cm}$ (i.e., approximately 12 th year of life) almost all the individuals (95.54\%) were mature, males being slightly more numerous than females ( $55.95 \%$ and $44.05 \%$, respectively).

Kock (1981), following Thurow, considers $\mathrm{L}_{\mathrm{m}}$, the length at the first maturity, to be the size at which $50 \%$ of the individuals are mature. In our case $\mathrm{L}_{\mathrm{m}}=37.5 \mathrm{~cm}$. Thus $\dot{N}$.gibberifrons mature rather late. Beverton (1963) introduced $\mathrm{L}_{\mathrm{m}} / \mathrm{L}_{\infty}$ as an index describing the fish growth potential after the sexual maturity has been attained. The index for N.gibberifrons off South Georgia is $37.5 \mathrm{~cm} / 57.5 \mathrm{~cm}=0.65$, i.e., $65 \%$ of $\mathrm{L}_{\infty}$. Indices for other Antarctic species (off South Georgia) can be invoked here as given by Kock (1981): Champsocephalus gunnari matures after $34 \%$ of $\mathrm{L}_{\infty}$; Pseudochaenichthys georgianus - after $67 \%$ of $\mathrm{L}_{\infty}$; females and males of Chaenocephalus aceratus mature at $61 \%$ and $80 \%$ of $\mathrm{L}_{\infty}$, respectively. Another index can be $\mathrm{L}_{\mathrm{m}} / \mathrm{L}_{\mathrm{max}}$, where $\mathrm{L}_{\max }$ is the largest fish observed in the catch (Kock, 1981). Off South Georgia, Sust and Pinskaja (1978) observed $\mathrm{L}_{\max }=52 \mathrm{~cm}$; in Skóra's (1979) data, $\mathrm{L}_{\max }=53 \mathrm{~cm}$. Thus $\mathrm{L}_{\mathrm{m}} / \mathrm{L}_{\max }$ $=37.5 \mathrm{~cm} / 53 \mathrm{~cm}=0.7$, i.e., $70 \%$. 


\section{DISCUSSION}

A few authors only have studied age and growth rate of N.gibberifrons. Boronin and Frolkina (1976) determined age from scales and otoliths; furthermore, they found out that scale annual rings had been started during the austral winter (May-September in juveniles and July in mature individuals). According to North et al. (1980), hyaline zones on otoliths of the species are started during the austral winter as well. This is presumably a character common to the notothenids, as shown i.a., by Hureau (1970) and Hureau and Ozouf-Costaz (1980). Boronin and Frolkina (op. cit.) observed the first four annual rings on the N.gibberifrons scales to be very poorly set off, which they ascribed to the presumed presence of the species in upper or intermediate water layers during the initial years of life. To prevent errors in age calculations, those authors counted sclerites on those scales that displyed well-marked initial annual rings (zones of densely packed sclerites). Boronin and Frolkina assumed each annual zone to correspond to a certain number of sclerites. Their results confirmed their hypothesis. Thus the fish age can be estimated by counting sclerites on scales with poorly marked initial rings. Unfortunately, this procedure cannot be applied to back calculations. Sust and Pinskaja (1978) studied, i.a., the growth rate of $N$.gibberifrons by scale back reading on the assumption of a direct relationship between the scale radius and fish total length. Skóra (1979) dealed with the N.gibberifrons growth rate, too, without, however, giving any indication as to the procedure used. Ciechanowski (1980) used scales to back calculate the N.gibberifrons growth rate; he used Wowk's procedure and applied the curvilinear relationship between the scale radius and fish length. Having collected no individuals smaller than $19 \mathrm{~cm}$, he assumed a simplified course of the relationship for the smaller fishes and plotted a tangent to the curve from the origin.

North et al. (1980), when examining procedures for N.gibberifrons age determinations, found the scales difficult to interpret: age readings taken from different scales of the same fish showed no agreement whatsoever. The scales showed numerous double and/or false rings difficult to distinguish from the proper ones; moreover, in older fishes' scales it was difficult to separate rings located close to the scale margin. The observations of North et al. (1980) are in a complete agreement with those made by the present author. On the other hand, they found the otoliths, burned and broken, to be readable.

Kelle (1982) studied in detail the utility of various organs of N.gibberifrons in age determination and concluded that scales were the best tools for the purpose. He measured between-sclerite distances, stained the scales with silver nitrate, made photographic prints, examined augmented images of the scales on TV screen, and viewed the scales in polarised light. He also considered otoliths to be applicable in age determinations, many otoliths, however, being poorly readable. Kelle used various treatments to increase the otolith legibility and found thin polished sections to be most suitable. However, he did not try the traditional, well-used technique of otolith burning.

As shown in section on back calculations, the N.gibberifrons otoliths can be used in the growth rate back calculations. However, there is a lingering question of how reliable 
the values of $\mathrm{L}_{1}$ and $\mathrm{L}_{2}$ obtained in this way are. Furthermore, it would be interesting to solve the problem of scale growth start. The present author had no individuals smaller than $13.5 \mathrm{~cm}$ at his disposal. Presumably, the juveniles of the species are pelagic, thus avoiding the demersal trawl. One can, however, make an attempt to solve those problems in part at least, based on the existing studies on N.gibberifrons larvae. Such studies have been scarce so far. Efremenko (1979) described the N.gibberifrons larvae caught in the upper $100 \mathrm{~m}$ of the South Georgia shelf waters between November and February. The total length of the individuals caught ranged within $8.5-38.5 \mathrm{~mm}$. Wörner and James (1981) described the N.gibberifrons larvae caught off South Georgia and in the Bransfield Strait. The mean length of the fish caught off South Georgia in November and December 1975 was $21 \mathrm{~mm}$. Slósarczyk (in press) found that krill catches off South Georgia on April 11-17, 1981 contained a by-catch consisting of, i.a., N.gibberifrons larvae measuring (SL) $33-41 \mathrm{~mm}$, which corresponds to the total length of approximately $40-47 \mathrm{~mm}$. Two of the larvae collected he examined in detail (Slósarczyk, pers.comm.). The first, measuring (total length) $46.5 \mathrm{~mm}$, had single scales scattered on the sides, dorsal part, above and behind the pectoral fins. The scales showed 4 sclerites, an empty space and a beginning of the fifth one being observed beyond the last one. The other larva, $44 \mathrm{~mm}$ long (total length) displayed no scales.

N.gibberifrons spawns during the austral winter (Boronin and Frolkina, 1976; Skóra, 1979; Wörner and James, 1981). From this time till November-December the juvenile fish attain about $21 \mathrm{~mm}$ of the total length and measure $40-47 \mathrm{~mm}$ in April next year, which is more than $\mathrm{L}_{1}$ calculated from equation (3). As determined by Boronin and Frolkina (1976), the period of annual ring formation on scales of the immature fish is fairly long, from May until September. The rings in various individuals can form at different times. Maybe the period of the hyaline zone formation on scales of the immature fish is equally long and takes place at different times in different individuals, too. That could partly account for the wide range of sizes back calculated for the initial period of life.

It seems quite probable that between April $(40-47 \mathrm{~mm})$ and the termination of the hyaline zone formation the juvenile N.gibberifrons grow to attain the mean length of $60.3 \mathrm{~mm}$, which is the $\mathrm{L}_{1}$ value as estimated with the second back calculation procedure. Therefore the $\mathrm{L}_{1}$ values obtained with this method should be considered more reliable.

As seen from the preliminary observations by Slósarczyk already referred to, the larvae start the scales in April. More comprehensive studies on larval biology are needed before the question whether the scales will appear in all the fish by the end of the austral summer and if 19-25 sclerites (the average number given by Boronin and Frolkina, 1976 as occurring in front of the first ring) will have time to form can be observed.

\section{REFERENCES}

Beverton R.J.H., 1963: Maturation, growth and mortality of clupeid and engraulid stocks in relation to fishing. Rapp. Proc.-Verb.Cons. int. Explor. Mer, 154: 44-67. 
Boronin V.A., Frolkina Zh.A., 1976: Opredelenie vozrasta zielonoj nototenii [Notothenia gibberifrons Lönnb.; semejstvo Nototheniidae] jugo-zapadnoj Atlantiki. [Age determination of green notothenia(Notothenia gibberifrons Lönnb., Nototheniidae)]- Trudy AtlantNIRO, vyp. 60: 29-37. (in Russian)

Boronin V.A., Altman J.S., 1979: Rost i jestestviennaja smiertnost zielonoj nototenii. [Growth and natural mortality of green notothenia]. - Trudy AtlantNIRO, vyp. 81:66-71.

Ciechanowski P., 1980: Charakterystyka biologiczno-połowowa dwóch gatunków z rodzaju Notothenia ze szczególnym uwzględnieniem wieku i tempa wzrostu na podstawie rejsu m.t. „Bogar” w rejon Georgii Południowej w okresie 7.06.-21.11.1979. [Biological and exploitational characteristics of two Notothenia species, with a particular reference to age and growth rate; MT „Bogar”'s cruise off South Georgia from June 7 - November 21, 1979. M.Sc.Thesis manuscript]. Praca magist., maszynopis. Zakł. Biol. Zasobów Morza A.R. Szczecin.

Efremenko V.N., 1979: Ličinki Šesti vidov ryb sem.Nototheniidae iz moria Skotia. [Descriptions of larvae of six species of the family Nototheniidae from the Scotia Sea]. - Voprosy Ichtiologii, 19, 6(119): 1068-1078.

Hureau J.C., 1970: Biologie comparée de quelques poissons antarctiques (Nototheniidae).- Bull. Inst. oceanogr. Monaco, 68: 1-244.

Hureau J.C., Ozouf-Costaz C., 1980: Age determination and growth of Dissostichus eleginoides Smitt, 1898 from Kerguellen and Crozet Islands.-Cybium $3^{\mathrm{e}}$ série, $\mathrm{n}^{\mathrm{O}}$ 8: $23-32$.

Kelle W., 1982: Probleme und Methoden der Alterbestimmung an Notothenia gibberifrons Lönnberg, 1905. - Archiv. für Fischereiwissenschaft. 33, 1/2: 69-78.

Kock K.H., 1978: Fischereibiologische Untersuchungen. (in) Sahrhage D., Schreiber W., Steinberg R., Hempel G.: Antarktis-Expedition 1975/1976 der Bundesrepublik Deutschland.-Arch. Fischwiss. 29, 1: 41-57.

Kock K.H., 1979: Fischereibiologische Untersuchungen an Fischen. (in) Hempel G., Sahrhage D., Schreiber W., Steinberg R.: Antarktis-Expedition 1977/78 der Bundesrepublik Deutschland.Arch. FischWiss. 30, 1: 71-84.

Kock K.H., 1981: Fischereibiologische Untersuchungen an drei antarktischen Fischarten: Champsocephalus gunnari Lönnberg, 1905, Chaenocephalus aceratus (Lönnberg, 1906) und Pseudochaenichthys georgianus Norman, 1937 (Notothenioidea, Channichthyidae). - Mitteilungen aus dem Institut für Seefischerei der Bundesforschungsanstalt für Fischerei No 32: 1-226.

Kock K.H., 1982: Fischereibiologische Untersuchungen bei Elephant Island im März 1981. - Arch. Fisch Wiss. 33, 1: 127-142.

North A.W., White M.G., Burchett M.S., 1980: Age determination of Antarctic fish.-Cybium, $3^{\circ}$ série, 8: $7-11$.

Šust K.V., Pinskaja I.A., 1978: Vozrast i tempo rosta ßesti vidov nototenievych ryb (semejstvo Nototheniidae). [Age and growth of six species of Nototheniid fish (Family Nototheniidae)]. Vopr. Icht. 18, 5(112): 837-843.(in Russian)

Skóra K.E., 1979: Charakterystyka biologiczna i eksploatacyjna nototenii żółtej (Notothenia gibberifrons) z łowisk antarktycznych w sezonie 1978/79 (w) MIR Zakład Ichtiologii. ,,Badania biologiczno-rybackie i ocena stanu zasobów rybriych wód Antarktyki w sezonie 1978/79" [Biological and exploitational characteristics of Notothenia gibberifrons from Antarctıc fishing grounds in 1978/1979]. MIR - Zakład Ichtiologii. Gdynia: 69-86.

Slósarczyk W. (in press)' Preliminary estimation of abundance of juvenile Nototheniidae and Channichthyidae within krill swarms off South Georgia. - Acta Ichth. et Pisc. XIII, 1:

Wörner F.G., James R., 1981: Early life history stages of the Antarcic fish Notothenia gibberifrons Lönnberg, 1905. - Rapp. P.-V. Réun. Cons. int. Explor. Mer, 178: 196.

Vovk F.J., 1955: O metodikie rekonstrukcji rosta ryb po češuje.. -Trudy Biol. Stan. „Borok”, AN SSSR, vyp. 2: 351-392. (in Russian)

Translated: Dr. Teresa Radziejewska 
Andrzej KOMPOWSKI

\author{
BADANIA NAD SZYBKOŚCIĄ WZROSTU ŻÓŁTEJ NOTOTENII, \\ NOTOTHENIA GIBBERIFRONS LÖNNBERG, 1905 Z REJONU PD. GEORGII
}

\title{
STRESZCZENIE
}

Materiał zebrano na łowiskach Pd. Georgii w marcu i maju 1981 r. (tab. 1). Między długością całkowitą (1.t) i długością ciała (1.c.) istnieje zależność: 1.c. $=0.8848$ 1.t. -0.3801 . W połowach występowały ryby o długości od 13.5 do $50.0 \mathrm{~cm}$ (rys. 4) i wieku od $2+$ do $23+$ lat. Wykazano nieprzydatność łusek do odczytów wstecznych szybkości wzrostu ze względu na słabą czytelność środkowych partii, a u ryb starszych - iównież części peryferyjnych (rys. 7). Zależność między długością promienia oralnego łuski $(\mathrm{V})$ i długością całkowitą ryby jest krzywoliniowa wg równania: $\mathrm{V}=-22.3487+3.9466$ 1.t. -0.024771. t. $^{2}$. Krzywa wyrażona tym równaniem przecina oś odciętych w miejscu odpowiadającym $5.8 \mathrm{~cm}$ długości całkowitej ryby, co sugeruje zakładanie się łusek u N.gibberifrons, gdy osobniki tego gatunku mają przeciętnie $5.8 \mathrm{~cm}$. Wykazano przydatność prażonych i przełamywanych otolitów do odczytów wstecznych szybkości wzrostu. Zależność między grzbietowym promieniem powierzchni przekroju otolitu i długością cał kowitą ryby wyraża się dla ryb o zakresie długości $13.5 \mathrm{~cm}$ do $49.5 \mathrm{~cm}$ równaniem: $\mathrm{V}=0.07239$ l.t. +0.3764 (rys. 9). Obliczone dwiema metodami wartości $L_{n}$ są podane w tab. 3 i 4 . Wiarygodniejsze są $L_{1}$ i $L_{2}$ obliczone metodą Wowka. W oparciu o dane $\mathrm{z}$ tabeli 3 (pomijając $\mathrm{L}_{1}, \mathrm{~L}_{2}$ i $\mathrm{L}_{3}$ ) oszacowano następujące parametry równania von Bertalanffy'ego: $\mathrm{L}_{\infty}=57.48 \mathrm{~cm} ; \mathrm{K}=0.104 ; \mathrm{t}_{0}=0.4391$ roku. Żółta nototenia osiaga pierwszą dojrzałość płciową przy długości całkowitej $37.5 \mathrm{~cm}$, co odpowiada $0.65 \% \mathrm{~L}_{\infty}$.

\section{Andrzej KOMPOWSKI}

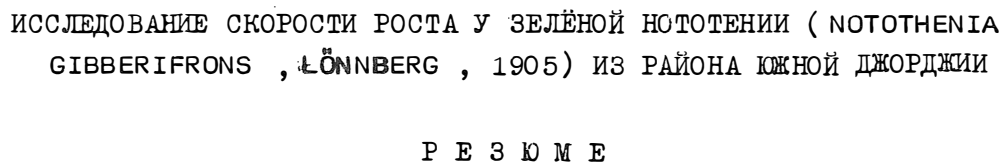

Материал был собран по местам ловли на территории южной Джорджии на протяжении месяцев марта и мая 1981 г. (таб.1). Между длиной в целом ( l.t) и длиной тела (1.с.) существует зависимость: 1.с. = 0.8848 1.t.-0.3801. Из ловли была получена рыба длиной с 13,5 до 50,0 см (рис.4) и в возрасте с 2+ до 23+ лет. Установлено непригодность чешуи для обратных расчислений темпа роста из-за небольщой чёткости центральных участков, а у более старых особей - такхе периферийных участков (рис.7). Зависимость между длиною орального радиуса чешуи (V) и полной длиною рыбы является криволинейной: $\quad V=-22.3487+3.9466$ l.t.- -0,02477 l.t? Кривая, изображенная этим уравнением пересекает ось абсцисс в точке соответстующей величине 5,8 см полной длины. На основании этого можно предполагать, что у 
N.gibberifrons заклапка чепуи происходит, когда особи этого вида представляют собой в среднем 5,8 см длины. Показана пригодность каленньх и преодоленных отолитов для обратных расчирлений темпа роста. Для рыбы длиной с 13,5 см до 49,5 см зависимость мехду хребтовым радиусом поверхности разреза отолита и полною длиною рыбы изображает уравнение: $v=0.072391 . t_{0}+0,3764$ (рис.9).

Величины $L_{n}$, вычисленные с употреблением двух методов, составлены по таб. 3 и 4 .

Более достоверными являотся величины $L_{1}$ и $L_{2}$ вычисленные по методу Вовка. На основании данных, составленных в таб.3 (ха исключением $L_{1}, L_{2} L_{3}$ ) оценивались следующие параметры уравнения von Bertalanffy:L $L_{\infty}=57.48 \mathrm{~cm}$; $K=0.104 ; \quad t_{0}=0.4391$ года. $\mathrm{Y}$ зелёной нототении первая половая. спедость

Author's address:

Doc. dr hab. Andrzej Kompowski

Received: 8 July 1983

Instytut Oceanografii

ul. Kazimierza Królewicza 4

71-550 Szczecin, Polska (Poland) 